\title{
IDENTIFIKASI DAN KELIMPAHAN PLANKTON DI PULAU MAMBURIT KABUPATEN SUMENEP
}

\author{
Identification And Profusion of Plankton In Mamburit Island, Sumenep District \\ Sawiya $^{1}$, Diana Arfiati ${ }^{2}$, Guntur ${ }^{2}$, Ummi Zakiya ${ }^{2}$ \\ ${ }^{1}$ Universitas Ibrahimy Situbondo \\ ${ }^{2}$ Fakultas Perikanan dan Ilmu Kelautan, Universitas Brawijaya, Malang \\ sasa.syahid@yahoo.com
}

\begin{abstract}
ABSTRAK
Plankton merupakan organisme kebanyakan hidupnya melayang-layang dan mengapung di perairan dan pergerakan yang terbatas sehingga sangat tergantung pada arus yang membawa ke mana-mana. Plankton mempunyai peranan penting bagi organisme terutama di laut. Tujuan penelitian ini untuk mengetahui ada berapa spesies yang ditemukan di pulau Mamburit. Metode yang digunakan sampel plankton di ambil dengan ukuran plankton-net berukuran $2 \mathrm{~mm}$ sedangkan identifikasi dan pencacahan menggunakan dengan metode sensus (SCR), dengan acuan indentifikasi. Kelimpahan phytoplankton dan zooplankton pada ulangan 1 lokasi windward 1 dan windward II tidak terdapat plankton, leeward 1 ditemukan hanya 1 jenis spesies Synedra flugens, dengan jumlah total 13,32 ind/liter, pada lokasi dan leeward II, ditemukan 2 jenis spesies, Pleurosigma, Synedra flugens jumlah total yang ditemukan dari 2 spesies 19,98 ind/liter, sedangkan pada ulangan 2 ditemukan 4 spesies Synedra Flugens, Pleurosigma, Rhizosolenia borealis, Nauplius, dengan jumlah windward I 99,96 ind/liter, Leeward 1 ditemukan 1 spesies, Rhizosolenia borealis, dengan jumlah total 6,66 ind/liter,. Windward II tidak ditemukan sama sekali, dan leeward II ditemukan 2 spesies Synedra Flugens, Nitzschia dengan jumlah total 13,32 ind/liter.

Kata Kunci : Pulau Mamburit, kelimpahan plankton,
\end{abstract}

\section{ABSTRACT}

Plankton is an organism, most of them live hovering and floating in the water with limited movement wich most of them live hovering and floating in the water with limited movement where the stream brings. Plankton has an important role for other organisms, especially in the sea because plankton is a primary producer wich is a food-produser organism. Plankton has never been identified on Mamburit Island, the purpose of this study is to find out how many species were found on Mamburit Island in each of the windward 1 and windward II locations, leeward 1 leeward II twice replication. The results obtained that phytoplankton and zooplankton replication 1 at location of windward 1 and windward II did not have plankton, leeward 1 was found only 1 species of Synedra flugens, 13.32 ind/liter, on location and leeward II, found 2 species, Pleurosigma, and Synedra flugens such as 2 species 19.98 ind / liter, while in replication 2 found 4 species of Synedra Flugens, Pleurosigma, Rhizosolenia borealis, Nauplius, with the number of windward I was 99.96 ind/liter, Leeward 1 was found 1 species, Rhizosolenia borealis, with a total of 6.66 ind / liter. Windward II was not 
found at all, and leeward II was found in 2 species of Synedra Flugens, Nitzschia with a total of 13.32 ind / liter.

Keywords: Mamburit Island, Plankton Abundance

\section{PENDAHULUAN}

Pulau Mamburit merupakan salah satu pulau yang berada di kepulaun Kangean yaitu zona pemukinan di mana pada zona ini masyarakat melakukan pekerjaan sebagai nelayan menangkap ikan, zona selanjutnya adalah wisata selam di mana para pengunjung akan menikmati indah terumbu karang di bawah laut. Dengan aktifitas yang berbeda maka akan mendapatkan suatu kesuburan perairan pulau Mamburit dengan melihat kelimpahan plankton.

Plankton terbagi jadi dua antara lain: fitoplankton dan zooplankton. Zooplankton merupakan pemakan herbivora dan karnivora yang bersifat planktonic dan bersifat konsumen tingkat pertama yang akan langsung memangsa fitoplakton sedangkan fitoplankton merupakan tumbuhan mikroskopis yang hidupnya kebanyakan melayang-layang di permukaan air dan mempunyai sifat autotroph dan menjadi produsen primer di suatu perairan (Sachlan M, 1982). Sedangkan plankton perairan tidak selalu memberikan manfaat yang baik ada beberapa plankton yang menimbulkan merugikan apa bila dari salah satu jenis plankton tertentu dan melebihi dari ambang batas makan akan menyebabkan blooming plankton, hal ini akan menyebabkan kerusakan keseimbangan suatu perairan.

Parameter lingkungan mempunyai peranan penting bagi kelangsungan hidup dan kelimpahan atau distribusi plankton.

Ada beberapa aktifitas yang dilakukan di perairan mamburit yang akan menyebabkan penurunan kelimpahan plankton antara lain pembuangan sampah ke laut, pembuangan minyak sisa nelayan dan lain-lain.

\section{METODE PENELITIAN}

Penelitian ini dilaksanakan pada bulan Maret pada 4 lokasi antara lain windwar 1 dan windward II, leeward 1, leeward II, dengan dilakukan pengambilan 2 kali dengan interval 2 minggu sekali. Analisis cair dan zooplankton dilakukan di Laboratorium Ilmu Kelautan Universitas Trunojoyo Madura, sampel plankton di ambil dengan jaring plankton berukuran $2 \mathrm{~mm}$ sedangkan identifikasi dan pencacahan menggunakan dengan metode sensus (SCR), dengan acuan indentifikasi,

Analisis data perhitungan kelimpahan plankton hal ini dilakukan 
untuk mendapatkan seberapa besar phytoplankton spesies Synedra flugens kelimpahan genus tertentu yang 6,66 ind/liter, Pleurosigma 13,32 ind/liter ditemukan selama melakukan dengan jumlah total 19,98 ind/liter. Pada pengamatan. Rumus kelimpahan plankton sebagai berikut:

$$
N=\frac{n X A \operatorname{cg} x V t}{\operatorname{Aax} V s X A s}
$$

Keterangan :

$\mathrm{N} \quad$ : Kelimpahan plankton (sel/I)

$\mathrm{N} \quad$ : Jumlah sel yang teramati (sel)

Vs : Volume contoh air yang disaring (I)

Acg : Luas penampang permukaan

\section{PEMBAHASAN}

Hasil penelitian menunjukkan di temukan 6 jenis plankton di pulau Mamburit, ada beberapa lokasi yang tidak terdapat plankton pada ulangan pertama di antaranya windward 1 dan windward II hal ini kemungkinan besar pengaruh dari lokasi yang mana widnward mempunyai lokasi yang menghadap ke angin artinya di lokasi ini terdapat arus yang begitu cepat apabila di bandingkan dengan Leeward, sedangkan lokasi leeward 1 dan leeward II di temukan jenis phytoplankton dan jenis zooxplanton, pada windward 1 dan windward II tidak ditemukan, phytoplankton maupun zooplankton lokasi leeward 1 ditemukan ada 2 jenis phytoplankton antara lain spesies Synedra flugen 13,32 ind/liter, leeward II ada 3 spesies yang ditemukan jenis ulangan pertama ditemukan hanya jenis kelas phytoplankton sedangkan lokasi yang ditemukan hanya dua lokasi leeward 1 dan leeward II.

Sedangkan pada ulangan II ditemukan pada lokasi windward 1 phyplankton antara lain spesies : Synedra Flugens 19,98 ind/liter, Pleurosigma, 6,66 ind/liter Rhizosolenia borealis 6,66 ind/liter, dan zooplankton 1 jenis nauplius sebanyak 6,66 ind/liter dan jumlah total mencapai 99,96 ind/liter, pada Leeward 1 hanya ditemukan 1 spesies Rhizosolenia borealis 6,66 ind/liter dengan total 6,66 ind/liter, pada windward II tidak ditemukan jenis phytoplankton maupun zooplankton hal ini kemungkinan di sebabkan oleh arus yang mempengaruhi plankton karena plankton yang hidupnya melayang-layang dan semakin cepat arus maka plankton yang ada di perairan akan ikut melayang dengan arus seiring arus (Nyabaken J,W, 1992). Pada lokasi Leeward II hanya di temukan pyhtoplankton 2 spesies Synedra flugens sebanyak 6,66 ind/liter, Nitzschia 6,66 ind/liter dengan jumlah total 13,32 ind/liter 
Dari masing-masing ulangan jumlah banyak bila dibandingkan dengan yang identifikasi yang paling banyak pada ditemukan di pulau mamburit lebih ulangan 2 sebanyak 7 spesies dan ulangan sedikit, hal ini berbanding terbalik dengan 1 ditemukan spesies, sedangkan apabila dan kecenderungan lebih banyak dibandingkan dengan penelitian lain di fitoplankton, hal ini terjadi diakibatkan lokasi yang berbeda yang ditemukan oleh proses predasi telah berjalan. Faktor Suharno \& Setyono (2009), dan Sujarta lain yang mempengaruhi kelangsungan (2005) menemukan 13 marga plankton, hidup plankton adalah faktor parameter dan Suharno et. al. (2009) di perairan lingkungan (Eko Winasis et. al., 2011). jayapura 52 jenis plankton hal ini lebih
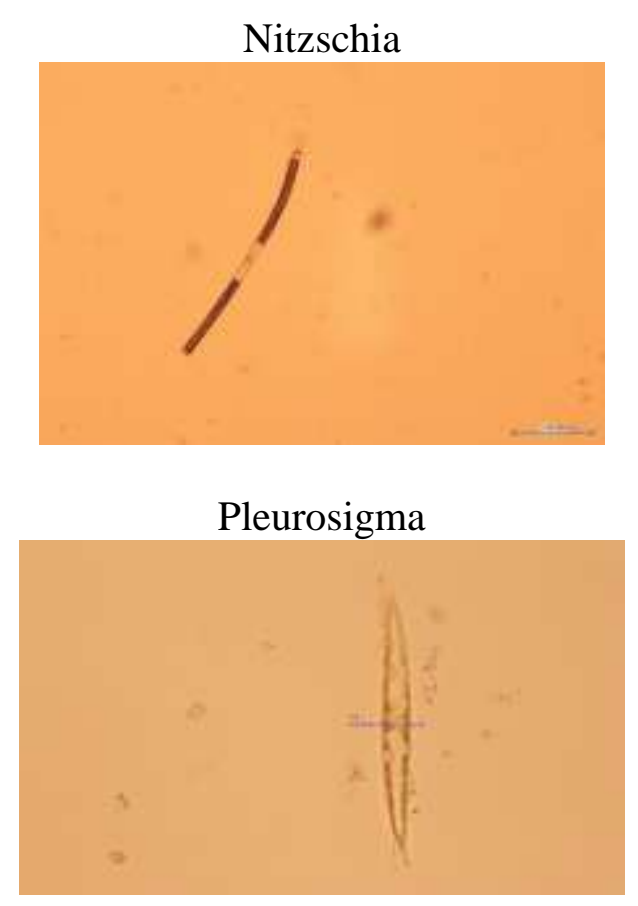

Nauplius

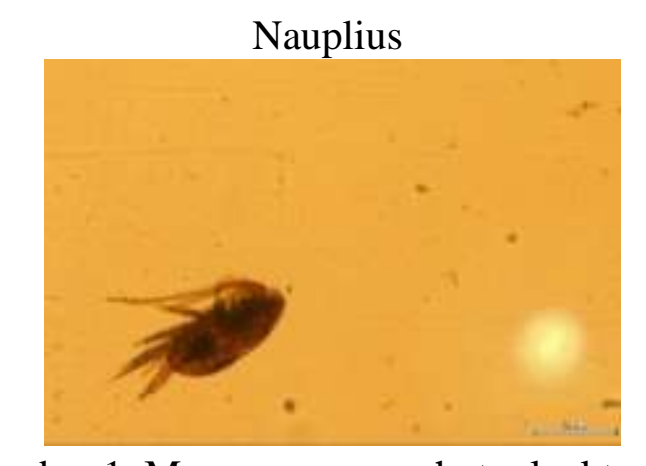

Gambar 1. Macam-macam phytoplankton dan zooplankton yang ditemukan

\section{the}

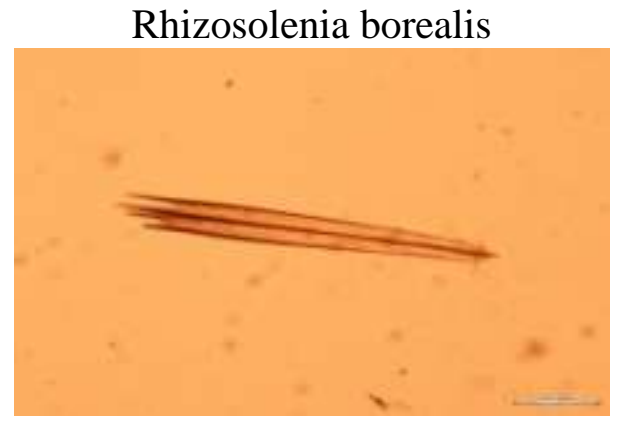

Synedra Flugens

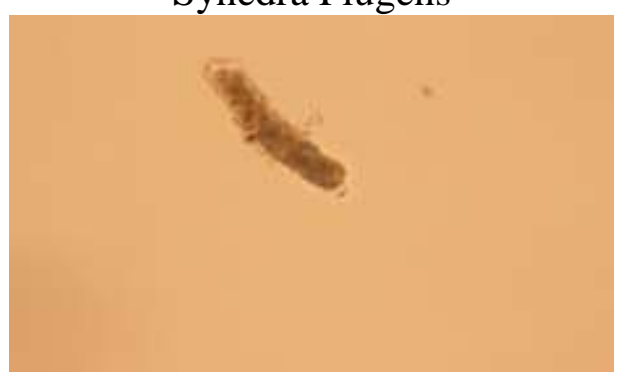




\section{KESIMPULAN}

Phytoplankton dan zooplankton pada ulangan 1 lokasi windward I dan windward II tidak terdapat plankton, leeward I ditemukan hanya 1 jenis spesies synedra flugens, 13,32 ind/liter, pada lokasi dan leeward II, ditemukan 2 jenis spesies, Pleurosigma, Synedra flugens jumlah total yang ditemukan dari 2 spesies 19,98 ind/liter, Sedangkan pada ulangan II ditemukan 5 Spesies lokasi windward 5 spesies Synedra Flugens, Pleurosigma, Rhizosolenia borealis, Nauplius, dengan total 53,28 ind/liter, Leeward 1 ditemukan 1 spesies Rhizosolenia borealis, dengan jumlah total $6,66 \mathrm{ind} /$ liter. Windward II tidak ditemukan sama sekali, dan leeward II ditemukan 2 spesies Synedra Flugens, Nitzschia dengan jumlah total 13,32 ind/liter.

\section{DAFTAR PUSTAKA}

Eko Winasih, (2011). Faktor-faktor yang Mempengaruhi Kelimpahan dan Dominasi Phytoplankton

Nyabaken, J. W. (1992). Biologi Laut. Suatu Pendekatan Ekologis. Terjemahan dari Marine Biology An Ecological Approach. Alih Bahasa; M. Eidman, Koesoebiono, D.G. Bengen dan M. Hutomo, Gramedia. Jakarta

Sachlan, M. (1982). Planktonologi. Corresspondence Course Centre.
Direktorat Jendral Perikanan. Departemen Pertanian. Jakarta.

Suharno dan P. Setyono. (2009). Keragaman Plankton di Muara Sungai Bian, Kabupaten MeraukePapua. Laporan Penelitian. Universitas Cenderawasih.

Suharno, Daniel lantang. (2009). Keragaman Jenis Plankton Di Perairan Laut Kot Jayapura, Papua. Jurnal Biologi Papua. Volume 2, Nomer 1 Hal: 1-6

Sujarta, P. (2005). Keanekaragaman Diatom (Divisi: Chrysophyta, Kelas: Bacillariophyceae) di Teluk Arguni, Kaimana-Papua. SAINS 5(2): 50-53. 